Article

\title{
The 3R Principles for Applying Biochar to Improve Soil Health
}

\author{
Mingxin Guo $\mathbb{D}$ \\ Department of Agriculture \& Natural Resources, Delaware State University, Dover, DE 19901, USA; \\ mguo@desu.edu; Tel.: +1-302-857-6479
}

Received: 22 October 2019; Accepted: 30 January 2020; Published: 4 February 2020

\begin{abstract}
Amending soil with biochar is a promising approach to persistently improve soil health and promote crop growth. The efficacy of soil biochar amendment, however, is soil specific, biochar dependent, and influenced by the biochar application programs. To maximize the benefits of biochar application, this paper proposes the $3 \mathrm{R}$ principles for applying biochar to soils: right biochar source, right application rate, and right placement in soil. The quality of biochar as a soil amendment varies significantly with the feedstock and the production conditions. Biochar products capable of everlastingly sustaining soil health are those with high stable organic carbon (OC) content and high water- and nutrient-holding capacities that are manufactured from uncontaminated biomass materials. Acidic, coarse-textured, highly leached soils respond remarkably more to biochar amendment than other types of soils. Soil amendment with particular biochars at as low as $0.1 \mathrm{mass} \%$ (equivalent to $2 \mathrm{Mg} \mathrm{ha}^{-1}$ ) may enhance the seasonal crop productivity. To achieve the evident, long-term soil health improvement effects, wood- and crop residue-derived biochars should be applied to soil at one time or cumulatively $2-5$ mass $\%$ and manure-derived biochars at 1-3 mass\% soil. Optimal amendment rates of particular biochar soil systems should be prescreened to ensure the $\mathrm{pH}$ of newly treated soils is less than 7.5 and the electrical conductivity (EC) below $2.7 \mathrm{dS} \mathrm{m}^{-1}$ (in 1:1 soil/water slurry). To maximize the soil health benefits while minimizing the erosion risk, biochar amendment should be implemented through broadcasting granular biochar in moistened conditions or in compost mixtures to cropland under low-wind weather followed by thorough and uniform incorporation into the 0-15 cm soil layer. Biochars are generally low in plant macronutrients and cannot serve as a major nutrient source (especially N) to plants. Combined chemical fertilization is necessary to realize the synergic beneficial effects of biochar amendment.
\end{abstract}

Keywords: biochar source; pyrolysis completeness; application rate; placement; soil health

\section{Introduction}

As a legacy of ancient inhabitants who added biomass-derived char to barren land, Terra Preta (in Portuguese meaning "dark earth") in the central Amazon basin remains more productive relative to the surrounding highly leached, strongly acidic Oxisols and Ultisols [1-4]. The discovery implicates that biochar is an effective amendment for persistently enhancing and sustaining soil health - "the continued capacity of soil to function as a vital living ecosystem that sustains plants, animals, and humans" [5]. Decades of intensive research have indicated that biochar, "the fine-grained or granular charcoal made from heating vegetative biomass, bones, manure solids, or other plant-derived organic residues in an oxygen-free or oxygen-limited environment and used as a soil amendment for agricultural and environmental purposes," is capable of improving soil health by ameliorating soil physical, chemical, and biological properties [6-9]. In general, biochar is porous, environmentally recalcitrant (stable), and high in specific surface area (SSA) and cation exchange capacity (CEC) [10-12]. Amendment with biochar reduces the bulk density and increases the water- and nutrient-retention of major agricultural soils [6]. Biochar, however, extends to 
a wide range of charcoal products from thermochemical treatments (i.e., pyrolysis and gasification) of diverse biomass materials. Depending on the feedstock source and the production conditions, biochar products may vary significantly in quality characteristics and, consequently, in the capability to enhance soil health. For instance, biochars derived from manures generally contain more nutrients on the dry mass basis than those derived from wood [13-15], while the products manufactured at higher pyrolysis temperature typically possess greater stable $\mathrm{C}$ fraction and higher mineral nutrient contents (except for $\mathrm{N}$ ) than the ones from the same feedstock processed at lower pyrolysis temperature [10,16]. After applied as a soil amendment in crop production and abandoned land reclamation, different biochars exhibited noticeably dissimilar capabilities for improving soil health properties and promoting plant growth [17-19]. The quality variation of differently sourced biochars is a major reason for justifying the inconsistence of reported research results on biochar amendment enhancing soil health and promoting crop growth [6-8].

The effects of biochar amendment on soil health also vary with the soil type and the amendment rate. Biochars normally have a high $\mathrm{pH}(1: 10 \mathrm{w} / \mathrm{w}$ water extract $)$ in the range of $8-11$ [6,13]. For acidic soils, biochar amendment reduces the soil acidity and subsequently improves the soil health; for alkaline soils, however, addition of biochar with significant liming values may deteriorate the overall soil health by introducing additional alkalinity. Addition of biochar typically increases the water-holding capacity (WHC) of coarse textured soils but influences little or even decreases the WHC of clayey or organic matter-rich soils [20,21]. At different application rates ranging from 0.5 mass $\%$ to 10.0 mass $\%$, biochar amendments altered soil physical, chemical, and biological properties to different extents [22-24]. When the application rate was too low or too high (varying with the biochar source and the soil type), the biochar effect on modifying the soil health became either insignificant or even unfavorable [9,25-27], respectively.

The 4R nutrient stewardship guidelines have been extensively followed in fertilizer application to manage soil nutrients for achieving maximal crop productivity and minimal environmental impacts: right fertilizer source, right application time, right application rate, and right placement to crops [28]. If any of the 4Rs is not scientifically determined to be "right", the entire fertilization program becomes "wrong" toward crop production and natural water production [29]. Similarly, biochar amendment to attain best soil health and crop productivity improvement effects also warrants the scientific selection on the biochar source, application rate, and biochar placement in soil. To date, however, there are no guidelines developed for practitioners to apply biochar for its optimal agricultural and environmental benefits. A common myth among crop producers and the general public is that "biochar is a miraculous material. Once applied with biochar, the soil will be forever fertile and no fertilizers are needed any longer." Such understanding on biochar and expectations from biochar amendment were constantly negated by the real results, discouraging triers and impacting the extensive adoption of biochar as a soil amendment. This paper is to propose and elucidate the $3 \mathrm{R}$ (right source, right rate, and right placement) principles for applying biochar to persistently improve soil health, with an additional aim to provide a better understanding of biochar and biochar application.

\section{The Mechanisms for Biochar to Improve Soil Health}

The health of a soil in a defined ecosystem describes how well the soil can fulfill its environmental functions: supporting plant growth, regulating water movement, recycling wastes, harboring living organisms, and buffering the atmospheric composition [30]. Soil health is a comprehensive expression of and also determined by the soil composition and properties. An array of soil physical, chemical, and biological properties have been adopted in the soil health assessment system, including soil $\mathrm{pH}$, salinity, sodicity, organic matter content, penetration resistance (hardness), bulk density, structure, aggregate stability, available water capacity, infiltration rate, CEC, erosion rating, root health rating, active carbon content, protein content, respiration rate, presence of earthworms, potentially mineralizable $\mathrm{N}$ content, available plant nutrient contents, and toxic element contents [31-33]. Recommended management practices to improve and sustain soil health extend to crop rotation, cover crop planting, conservation tillage, land application of crop residues, manure, and organic composts, agronomic fertilization, liming, and biochar amendment $[33,34]$. 
Biochar amendment enhances the overall health of a soil by rectifying its physical, chemical, and biological properties to plant favorable conditions. The environmentally recalcitrant material possesses remarkable water-holding and nutrient-retention capacities, able to help soil conserve water and nutrients [34]. Research has demonstrated that appropriate biochar amendment reduces soil bulk density and penetration resistance, increases soil porosity and hydraulic conductivity, and enhances soil aggregate stability and available water capacity (AWC) [20,35]. Biochar amendment also reduces soil acidity, elevates soil CEC, and improves soil fertility by introducing mineral nutrients and mitigating nutrient leaching losses [36]. Biochar amendment further furnishes degradable organic carbon (OC) to soil organisms and provides more favorable habitats to microbes and, therefore, facilitates soil biological activities [37]. As biochar can persist in natural soils for hundreds of years, the effect of biochar application on soil health improvement is of desirably long-term.

It is noteworthy that biomass residue-derived biochars are typically low in plant nutrients (particularly N) and, therefore, cannot serve as a major nutrient source to take place of chemical fertilizers in modern crop production. For instance, biochars manufactured from waste wood contained $<0.3 \% \mathrm{~N}$ and $<0.04 \% \mathrm{P}$ [15]. Crop residue-based biochars (e.g., from peanut hulls, rapeseed straw, wheat straw, corn stover, and switchgrass) showed a total $\mathrm{N}$ content $<2.7 \%$ and a total $\mathrm{P}$ content $<1.3 \%[11,16,38,39]$. Even manure-derived biochars (e.g., from pig manure solids, cow manure, and poultry litter) contained total $\mathrm{N}<4.2 \%$ and total $\mathrm{P}<3.2 \%[10,14,40]$. Manure- and animal bones-derived biochars may contain plant nutrients (e.g., P, K, Ca, S, B, Zn, and Cu) at considerable levels [10,41,42] and function as a supplemental nutrient source to crops. The fertilization effect of biochar through releasing the inherent nutrients, however, is temporary, diminishing over time and being inevident after one or a few growing seasons. It is the relatively high WHC and nutrient-retention capability of biochar that enable the material to facilitate soil health and crop growth. Soils amended with biochar at significant rates demonstrated noticeable improvements in AWC [43] and reductions in nutrient leaching losses [44,45]. Biomass residue-derived compost possesses comparable or even higher WHC and nutrient-retention capability, yet biochar is more advantageous owning to its high environmental recalcitrance, able to maintain the soil health improvement effect over hundreds of years [4]. It is the everlasting efficacy that entails biochar a preferred soil amendment. Notable improvements in plant growth and crop yield may be observed soon after manure-derived biochars are applied to soils without chemical fertilization [26]. These improvements are primarily a result of the minor nutrients (e.g., $\mathrm{P}, \mathrm{K}, \mathrm{Ca}, \mathrm{Mg}$, and $\mathrm{S}$ ) inherent in the biochar as ash components. This kind of obvious plant growth-stimulating effect is rather transient, generally disappearing in one growing season [44]. Biochar amendment may decrease the critical agronomic fertilization rates through reducing soil nutrient leaching losses [45,46]. To pursue the high crop productivity in modern agriculture, chemical fertilization remains essential to biochar-amended soils. Furthermore, the long-term soil health improvement effect of biochar amendment can only be achieved when appropriate selections of the biochar source, application rate, and placement in soil are simultaneously practiced.

\section{The Right Biochar Source}

Nearly all solid biomass residues serve as potential feedstocks for biochar. In research trials, more than fifty types of biomass residues have been tested to produce biochar, covering wood, forest litter, herbaceous debris, crop residues, yard trimmings, animal manures, sewage sludge, fruit and vegetable peels, nutshells, bones, coffee grounds, and cottonseed meal (Table 1). In commercial biochar production, wood and crop residues are the predominant feedstock due to their high availability and handling convenience. Nevertheless, wood from different tree species (e.g., softwood vs. hardwood) and from different parts or growth stages of a tree (e.g., bark, sapwood, and heartwood) varies in density and chemical constitution [47]. Since biomass materials are diverse in lignocellulosic (i.e., lignin, cellulose, and hemicellulose) and mineral element (e.g., $\mathrm{N}, \mathrm{P}, \mathrm{K}, \mathrm{S}, \mathrm{Ca}, \mathrm{Mg}, \mathrm{Na}$, and $\mathrm{Si}$ ) compositions, conversion of differently-sourced biomass materials to biochar even under the same carbonization conditions results in products dissimilar in physical and chemical characteristics (Table 1). In general, 
biochars derived from higher mineral element feedstocks (e.g., animal manures) demonstrate a higher mineral ash content, $\mathrm{pH}$, lime equivalence, and salinity while a lower OC content, SSA, and WHC than those derived from lower mineral element feedstocks (e.g., wood) (Table 1). Wood- and poultry litter-derived biochars prepared under the same $400{ }^{\circ} \mathrm{C}$ slow pyrolysis conditions, for instance, consisted of $76.3 \%$ and $36.1 \%$ OC, respectively and $4.0 \%$ and $56.6 \%$ ash minerals, respectively [48]. In addition, the pre-treatment of the feedstock in moisture content, particle size, and particle (envelope) density also impacts the product quality through influencing the carbonization process [13].

Table 1. Yield and quality variations of biochar as a function of the feedstock and production conditions [13,42,49-51].

\begin{tabular}{|c|c|c|c|c|c|c|c|c|c|c|}
\hline Feedstock & $\begin{array}{l}\text { Production } \\
\text { Conditions }\end{array}$ & Yield $t$ & pH & $\begin{array}{l}\text { Ash } \mathbb{I} \\
\mathrm{g} \mathrm{kg}^{-1}\end{array}$ & $\begin{array}{c}\text { CEC } \\
\text { cmol }_{\mathrm{c}} \mathbf{k g}^{-1}\end{array}$ & $\begin{array}{c}\text { SSA } \\
\mathrm{m}^{2} \mathrm{~g}^{-1}\end{array}$ & $\begin{array}{l}\text { WHCS } \\
\mathrm{g} \mathrm{g}^{-1}\end{array}$ & $\begin{array}{c}\mathrm{TN} \\
\mathrm{g} \mathrm{kg}^{-1}\end{array}$ & $\begin{array}{c}\mathrm{TP} \\
\mathrm{g} \mathrm{kg}^{-1}\end{array}$ & $\begin{array}{c}\text { TK } \\
\mathrm{g} \mathrm{kg}^{-1}\end{array}$ \\
\hline Hard wood & $400^{\circ} \mathrm{C}$ slow pyrolysis & $32.7 \%$ & 7.5 & 32.0 & 7.9 & 15.4 & 1.40 & 2.5 & 0.18 & 3.0 \\
\hline Hard wood & $500{ }^{\circ} \mathrm{C}$ slow pyrolysis & $25.8 \%$ & 8.2 & 42.0 & 7.5 & 26.6 & 1.44 & 3.0 & 0.34 & 3.6 \\
\hline Poplar wood & $400^{\circ} \mathrm{C}$ slow pyrolysis & $32.0 \%$ & 9.0 & 19.0 & 144 & 3.0 & & 7.8 & 0.44 & 4.2 \\
\hline Pine chips & $400{ }^{\circ} \mathrm{C}$ slow pyrolysis & $35.0 \%$ & 7.6 & & 7.3 & & & 2.6 & 0.15 & 1.4 \\
\hline Pine chips & $500{ }^{\circ} \mathrm{C}$ slow pyrolysis & $30.0 \%$ & 8.3 & & 5.0 & & & 2.2 & 0.16 & 1.5 \\
\hline $\begin{array}{l}\text { Spruce wood and } \\
\text { needle mix }\end{array}$ & $400^{\circ} \mathrm{C}$ slow pyrolysis & $36.0 \%$ & 6.9 & 35.0 & 73.5 & 1.8 & & 10.2 & 0.44 & 3.3 \\
\hline Switchgrass & $500^{\circ} \mathrm{C}$ slow pyrolysis & $29.0 \%$ & 8.0 & 78.0 & & 62.2 & & 4.3 & 2.4 & \\
\hline Rapeseed straw & $400^{\circ} \mathrm{C}$ slow pyrolysis & $39.4 \%$ & & 122.2 & & 16.0 & & 14.3 & & \\
\hline Rapeseed straw & $600{ }^{\circ} \mathrm{C}$ slow pyrolysis & $32.2 \%$ & & 138.5 & & 17.6 & & 15.3 & & \\
\hline Wheat straw & $400^{\circ} \mathrm{C}$ slow pyrolysis & $34.0 \%$ & 9.1 & 97.0 & 162 & 4.8 & & 10.5 & 1.3 & 19.9 \\
\hline Corn cobs & $450{ }^{\circ} \mathrm{C}$ slow pyrolysis & $26.4 \%$ & 10.3 & 65.2 & 71.1 & & & 11.9 & 2.9 & 25.6 \\
\hline Corn cobs & $500^{\circ} \mathrm{C}$ fast pyrolysis & $18.5 \%$ & 7.8 & & & $<1.0$ & & 8.5 & 4.4 & 43.4 \\
\hline Cotton stalk & $600^{\circ} \mathrm{C}$ slow pyrolysis & $28.0 \%$ & 10.3 & 95.0 & & 121 & & 48.0 & 4.8 & 28.5 \\
\hline Cottonseed meal & $30{ }^{\circ} \mathrm{C}$ slow pyrolysis & $53.3 \%$ & 9.1 & 137.0 & & $<1.0$ & 0.99 & 89.8 & 22.7 & 29.6 \\
\hline Cottonseed meal & $400^{\circ} \mathrm{C}$ slow pyrolysis & $40.8 \%$ & 10.1 & 173.3 & & $<1.0$ & 1.14 & 58.7 & 26.3 & 33.5 \\
\hline Cottonseed meal & $500^{\circ} \mathrm{C}$ slow pyrolysis & $35.1 \%$ & 10.2 & 193.0 & & $<1.0$ & 1.23 & 24.2 & 27.9 & 38.8 \\
\hline Cottonseed meal & $600^{\circ} \mathrm{C}$ slow pyrolysis & $29.4 \%$ & 10.3 & 212.7 & & $<1.0$ & 1.31 & 5.0 & 31.3 & 42.4 \\
\hline Poultry litter & $300{ }^{\circ} \mathrm{C}$ slow pyrolysis & $60.1 \%$ & 9.5 & 478.7 & 51.1 & 2.7 & 0.88 & 41.7 & 22.7 & 69.3 \\
\hline Poultry litter & $400^{\circ} \mathrm{C}$ slow pyrolysis & $56.2 \%$ & 10.3 & 566.2 & 41.7 & 3.9 & 1.01 & 26.3 & 26.3 & 81.2 \\
\hline Poultry litter & $500{ }^{\circ} \mathrm{C}$ slow pyrolysis & $51.5 \%$ & 10.7 & 605.8 & 35.8 & 4.8 & 0.99 & 12.1 & 27.9 & 87.9 \\
\hline Poultry litter & $600^{\circ} \mathrm{C}$ slow pyrolysis & $45.7 \%$ & 11.5 & 607.8 & 29.2 & 5.8 & 0.95 & 1.2 & 30.5 & 91.5 \\
\hline Pig manure solids & $420^{\circ} \mathrm{C}$ slow pyrolysis & $40.3 \%$ & 9.7 & 345.0 & & & & 21.1 & 38.5 & \\
\hline Cow manure & $400^{\circ} \mathrm{C}$ slow pyrolysis & & 9.0 & 703.0 & & & & 13.5 & 4.4 & \\
\hline Sewage sludge & $300^{\circ} \mathrm{C}$ slow pyrolysis & $67.5 \%$ & & 486.0 & & & & 36.0 & 79.0 & 7.7 \\
\hline Sewage sludge & $600^{\circ} \mathrm{C}$ slow pyrolysis & $44.2 \%$ & 9.7 & 591.0 & & 79.6 & & 33.0 & 198.0 & \\
\hline
\end{tabular}

+ Percent of the dry feed mass; $\ddagger$ in 1:5 solid/water extracts; II Mineral ash content; $§$ at 0.2 bar vacuum suction; CEC: cation exchange capacity; SSA: specific surface area; WHC: water-holding capacity; TN: total nitrogen content; TP: total phosphorus content; TK: total potassium content.

Carbonization of biomass residues to biochar is mostly realized through pyrolysis and gasification. Processing biomass materials by torrefaction and hydrothermal liquefaction generates black, char-like solids (so-called biocoal and hydrochar, respectively) that should not be viewed as biochar owning to the low stability of the products in natural soils [52-54]. The carbonization conditions as described chiefly in pyrolysis temperature (highest treatment temperature or peak temperature), reaction (solid residence) time, heating rate (heat transfer rate), and $\mathrm{O}_{2}$ availability influence greatly the yield and characteristics of the biochar products [55]. In general, carbonization transforms the biodegradable feed OC into more recalcitrant forms and enriches the ash minerals in biochar, with the effects increasing at higher pyrolysis temperature. Provided complete pyrolytic transformation of the feedstock at a particular peak temperature, the biochar products decreased in yield, total $\mathrm{N}$ content, CEC, and acidic surface functional groups while increased in stability, $\mathrm{pH}$, electrical conductivity (EC), mineral ash content, and SSA as the peak temperature was elevated in the range of $300-700{ }^{\circ} \mathrm{C}[10,48,49,56]$. The OC content of biochar is feedstock-dependent: The OC content of wood- and crop residue-derived biochars increased with raising the peak pyrolysis temperature between $300-700{ }^{\circ} \mathrm{C}[48,49,56]$, while the OC content of manure-derived biochars decreased gradually $[10,48]$. Even the post-treatment 
methods have great impacts on the biochar yield and properties. For example, heating at $105^{\circ} \mathrm{C}$ helped remove polycyclic aromatic hydrocarbons (PAHs) and other volatile organic hydrophobics remaining in biochar [57] while water washing reduced the soluble salts and organic toxics $[57,58]$. Cooling biochar right after carbonization using steam as practiced in many commercial biochar plants drastically increases the biochar SSA. At the cost of a slight yield decrease, this post-treatment engenders activated biochar products by simulating the activation process (using oxidizing agents such as steam, $\mathrm{O}_{2}$ and $\mathrm{CO}_{2}$ ) in activated carbon production [59].

The normal carbonization conditions in thermochemical processing of biomass materials by pyrolysis or gasification are listed in Table 2. There are two types of pyrolysis techniques: slow pyrolysis (aiming at biochar production) and fast pyrolysis (aiming at bio-oil generation). Gasification is targeted at harvesting syngas (a mixture of $\mathrm{CO}$ and $\mathrm{H}_{2}$ ). Treating organic residues by any of the three thermochemical techniques results in three products: char, pyrolysis bio-oil, and syngas, with the relative proportions shifting as a function of the carbonization conditions [60]. Biochar is the main product from slow pyrolysis yet a byproduct from fast pyrolysis or gasification of biomass residues. The peak temperature of slow pyrolysis for producing biochar covers a wide range from 300 to $700^{\circ} \mathrm{C}$, the heating rate (the speed of temperature rising in the center of feedstock particles in response to heat diffusion from the reactor) varies from $<1{ }^{\circ} \mathrm{C} / \mathrm{s}$ to $>50{ }^{\circ} \mathrm{C} / \mathrm{s}$, and the solid residence time (for the feedstock to undergo pyrolytic decomposition in the reactor) may extend from minutes to days (Table 2). The feedstock characteristics such as particle size, density, moisture content, and mineral ash composition also influence the carbonization process through interfering with the heating rate [61,62]. Dependent on the design of the carbonization system, air may incidentally enter into the reactor and affect the feed pyrolytic decomposition processes [55]. Any changes in the carbonization conditions and the feedstock preparation generate impacts on the yield and quality of the biochar products (Table 1). The optimal carbonization conditions are target product dependent, feedstock specific, and influenced by the design of the reactors (i.e., pyrolyzers and gasifiers). A higher peak temperature generally facilitates pyrolytic decomposition of organic matter, decreasing the yield while increasing the carbon stability of the biochar products $[10,48,49]$. At a determined peak temperature, adequate solid residence time is required to reach complete pyrolysis, a status at which the pyrolytic decomposition reactions are finished, the resulting biochar is potentially stabilized, and no further volatiles (e.g., smokes) are generated. The adequate solid residence time, however, is determined by the heating rate which is further controlled by the peak pyrolysis temperature and influenced by the feedstock preparation $[13,61,62]$.

Table 2. The carbonization conditions for thermochemically processing biomass residues using pyrolysis and gasification techniques $[13,61]$.

\begin{tabular}{|c|c|c|c|}
\hline \multirow{2}{*}{$\begin{array}{l}\text { Carbonization } \\
\text { Technique }\end{array}$} & \multicolumn{2}{|l|}{ Pyrolysis } & \multirow{2}{*}{ Gasification } \\
\hline & Slow Pyrolysis & Fast Pyrolysis & \\
\hline Feed particle size & $\begin{array}{l}\text { Chips to logs for batch reactors } \\
<10 \mathrm{~mm} \text { for moving-bed reactors }\end{array}$ & $<2 \mathrm{~mm}$ & $<5 \mathrm{~mm}$ \\
\hline Peak temperature & $\begin{array}{l}300-500{ }^{\circ} \mathrm{C} \text { for batch reactors } \\
500-700{ }^{\circ} \mathrm{C} \text { for moving-bed reactors }\end{array}$ & $700-1000{ }^{\circ} \mathrm{C}$ & $800-1200{ }^{\circ} \mathrm{C}$ \\
\hline Heating rate & $\begin{array}{c}<1^{\circ} \mathrm{C} / \mathrm{s} \text { in batch reactors } \\
5-50{ }^{\circ} \mathrm{C} / \mathrm{s} \text { in moving-bed reactors }\end{array}$ & $>200^{\circ} \mathrm{C} / \mathrm{s}$ & $>500{ }^{\circ} \mathrm{C} / \mathrm{s}$ \\
\hline Solid residence time & $\begin{array}{l}\text { Hours to days in batch reactors } \\
\text { Minutes in moving-bed reactors }\end{array}$ & Seconds & $<3 \mathrm{~s}$ \\
\hline $\mathrm{O}_{2}$ availability & $\mathrm{O}_{2}$-free & $\mathrm{O}_{2}$-free & Controlled air supply \\
\hline Main product & Charcoal & Bio-oil & Syngas \\
\hline Byproducts & Bio-oil and syngas & Char and syngas & Char and bio-oil \\
\hline Char yieldt & $\begin{array}{l}30 \%-40 \% \text { for batch reactors } \\
25 \%-35 \% \text { for moving-bed reactors }\end{array}$ & $15 \%-25 \%$ & $5 \%-15 \%$ \\
\hline
\end{tabular}

The International Biochar Initiative (IBI) suggests the following parameters in biochar quality assessment: $\mathrm{pH}$, lime equivalence, EC, mineral ash content, OC content, SSA, H/OC molar ratio (indicating stability), total and available $\mathrm{N}, \mathrm{P}, \mathrm{Ca}, \mathrm{Mg}$, and $\mathrm{S}$ contents, particle size distribution, 
germination inhibition assay, and contents of toxic elements and organic contaminants [63]. In addition, the stable proportion of OC, the surface acidic functional groups, CEC, and WHC should be directly measured and included in biochar quality evaluation [10]. The nutrient and water retention capabilities of biochar are largely governed by its CEC and SSA (or porosity). To achieve the long-term promoting effect on soil health, more recalcitrant (stable) biochar is preferred. Nevertheless, up to $65 \%$ of the OC in biochar products may be unstable, readily mineralizable to $0.056 \mathrm{M}$ acidic dichromate $[10,48]$. In wood-derived biochars (OC 720-842 $\mathrm{g} \mathrm{kg}^{-1}$ ) through $300-600{ }^{\circ} \mathrm{C}$ complete slow pyrolysis, the stable proportion of OC ranged from $91.8 \%$ to $95.1 \%$, slightly increasing as the pyrolysis temperature was elevated (Figure 1). In wheat straw-derived biochars (OC 658-716 g kg-1) from the same pyrolysis operations, the stable OC proportion was between $60.2 \%$ and $93.5 \%$. In poultry litter-derived biochars (OC $325-380 \mathrm{~g} \mathrm{~kg}^{-1}$ ), the stable OC proportion was in the range of $36.8 \%-86.3 \%$ (Figure 1). Without sufficient stable OC, the biochar products would be slowly mineralized once applied to soil, and the long-term effectiveness for sustaining soil health would be compromised. The $\mathrm{pH}, \mathrm{EC}$, lime equivalence, mineral ash content, and nutrient contents of biochar determine its temporary capabilities to neutralize soil acidity, modify soil salinity, and supply plant nutrients and, consequently, generate immediate yet transient effects on soil health and plant growth. In pursuit of the long-term soil conditioning effects, biochar products to be used as a soil amendment may be screened based on their stability (OC content $\times$ stable [ $>100$-year soil life] carbon proportion; H/OC molar ratio $<0.7$ ) indicating the environmental recalcitrance, SSA or porosity implicating the water-holding capacity, and CEC signifying the nutrient-retention capability $[10,49,56,64]$. Mineral soils typically have a CEC value of 3-20 $\mathrm{cmol}_{\mathrm{c}} \mathrm{kg}^{-1}$ (>10 $\mathrm{cmol}_{\mathrm{c}} \mathrm{kg}^{-1}$ implicating little nutrient leaching risk) and a BET-N $\mathrm{N}_{2}$ adsorption SSA value of $1-8 \mathrm{~m}^{2} \mathrm{~g}^{-1}[65,66]$. Accordingly, a quality biochar product should be high in CEC (e.g., $>20 \mathrm{cmol}_{\mathrm{c}} \mathrm{kg}^{-1}$ ), SSA (e.g., $>10 \mathrm{~m}^{2} \mathrm{~g}^{-1}$ ), and the stable proportion of OC (e.g., $>45 \%$ ). It is worth to mention that after applied to the field, biochar gradually increases its CEC and SSA from the originally low levels as result of natural weathering over time [67]. The unstable biochar OC is actually beneficial to soil microbes by serving as a carbon and energy source. The immediately water-extractable portion of the unstable OC, if at a significant content, can be harmful to seed germination and seedling development [57]. Further research is warranted to examine the effects of water extractable biochar OC on soil microorganisms and crop seedlings.

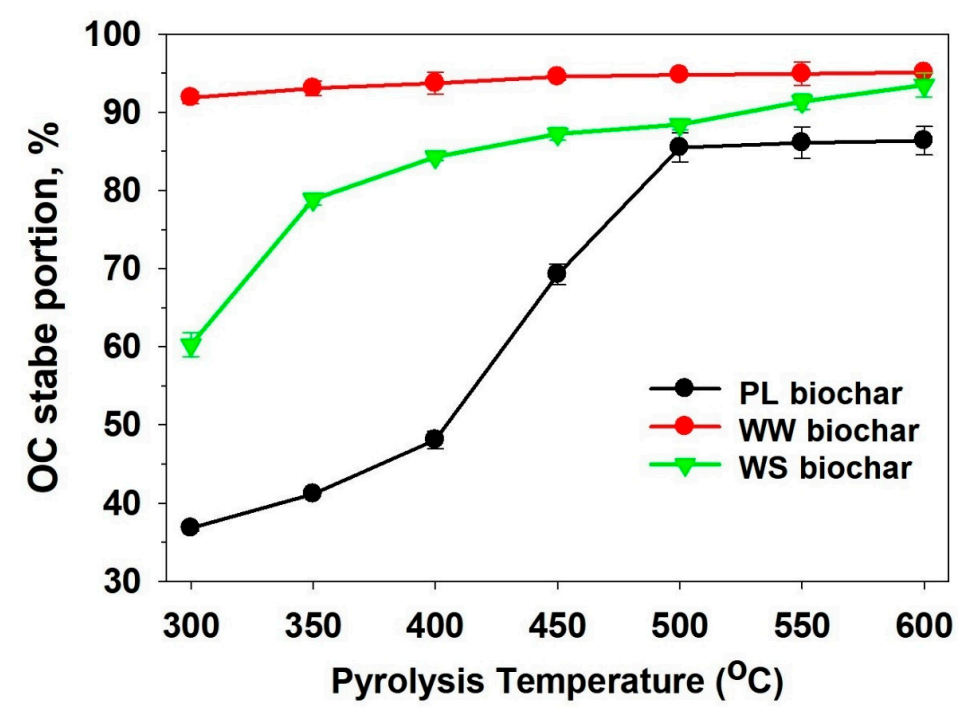

Figure 1. The stable proportion of organic carbon (OC) in biochars derived from waste wood (WW), wheat straw (WS), and poultry litter (PL) through complete slow pyrolysis at $300-600{ }^{\circ} \mathrm{C}$ peak temperatures. Error bars represent standard deviation of triplicate measurements. The stable OC content was measured in $<0.15 \mathrm{~mm}$ sample replicates using the dichromate oxidation methods [10]. 
Biochar is generally alkaline, demonstrating a $\mathrm{pH}$ value (in 1:5 solid/water slurries) in the range of 7.5-11.5 (Table 1). The alkalinity is attributed to the base metal (i.e., $\mathrm{Na}, \mathrm{K}, \mathrm{Ca}$, and $\mathrm{Mg}$ ) salts of the biochar mineral ash components that also furnish the biochar liming potential. Occasional acidic biochars with $\mathrm{pH}<7.0$ are likely products from incomplete pyrolysis (e.g., not adequate reaction time) that carry substantial instable OC and harmful organic acids (e.g., formic acid, acetic acid, hydroxybutyric acid, and benzoic acid) [13,60]. Research trials reported mostly negative responses of common crops to $\mathrm{pH}<7.0$ biochar amendments $[68,69]$. The presence of carboxylic groups may even entail biochars a negative value of lime equivalence. In a preliminary study using the $\mathrm{HCl}$ titration methods [70], we found that the lime equivalent of a $\mathrm{pH} 10.2$ wood-based commercial biochar was $-35.0 \mathrm{mg} \mathrm{g}^{-1}$, while for another $\mathrm{pH} 9.5$ wood-based biochar sample it was $118.1 \mathrm{mg} \mathrm{g}^{-1}$. Though the production conditions of these two biochars were unclear, it could be postulated that most organic acids in biochar were not active in natural circumstances (i.e., insoluble in water at room temperature) but their eventual dissolution in water would generate additional acidity. Manure-derived biochars contain significant contents of slowly releasable $\mathrm{P}, \mathrm{K}, \mathrm{Ca}, \mathrm{Mg}$, and S nutrients [10,71], but not do wood-based biochars. During high temperature (e.g., $\geq 500{ }^{\circ} \mathrm{C}$ ) pyrolysis, most of the manure $\mathrm{N}$ is lost in the pyrolysis vapor, resulting in biochar products fairly low in total $\mathrm{N}$ content and $\mathrm{N}$ availability [10]. In addition, biochar should be in small granules, as coarser particles are difficult to be evenly incorporated in soil. Commercial biochar products are usually in $0.05-6 \mathrm{~mm}$ particles. Field weathering will eventually disintegrate biochar particles to $<50 \mu \mathrm{m}(0.05 \mathrm{~mm})$ [72]. In general, wood- and crop residue-derived biochars possess significantly higher contents of stable OC yet lower contents of plant nutrients than manure-derived biochars. For long-term soil health improvement, wood- and crop residue-based granular biochars prepared through complete pyrolysis operations (i.e., with adequate reaction time) and demonstrating a pH level $>7.5$, a higher CEC value $\left(>20 \mathrm{cmol}_{\mathrm{C}} \mathrm{kg}^{-1}\right)$, and a higher SSA value $\left(>10 \mathrm{~m}^{2} \mathrm{~g}^{-1}\right)$ may be preferentially selected. To amend acidic, low fertility soils (e.g., abandoned mine land soil) where soil acidity reduction is necessary whereas regular fertilization is not affordable while rapid plant establishment is desired, manure-derived biochars generated at low pyrolysis temperature (e.g., $<500{ }^{\circ} \mathrm{C}$ ) and having a $\mathrm{pH}$ value $>9.0$ should be considered $(9.0$ is the lowest $\mathrm{pH}$ value reported for manure-derived biochars, Table 1).

\section{The Right Application Rate}

In general, biochar amendment enhances soil health and promotes plant growth. The effects, however, may not be evident if the application rate is not significant. Yet, at overly high application rates, negative effects may occur. In accordance with the biochar source and the soil type, appropriate amendment rates should be determined for achieving maximal benefits from amending soil with biochar.

In reported research trials, a wide range of biochar amendment rates was employed, from 0.1 to 15 mass $\%$ soil and mostly within $0.5-10$ mass $\%$ soil and more frequently in 1-5 mass $\%$ soil (roughly equivalent to 20 to $100 \mathrm{Mg} \mathrm{ha}^{-1}$ assuming the top $15 \mathrm{~cm}$ of field soil at a typical $1.4 \mathrm{~g} \mathrm{~cm}^{-3}$ bulk density is amended with biochar) $[6,17,22,45,57,73]$. At application rates $<1$ mass $\%$ soil $\left(20 \mathrm{Mg} \mathrm{ha}^{-1}\right.$ or $8 \mathrm{Mg} \mathrm{ac}^{-1}$ ), the effects of biochar amendment on soil physical properties such as bulk density, hydraulic conductivity, and water-holding capacity may be undetectable after a few months of natural weathering if the biochar is not highly porous to yield a tapped density $<0.1 \mathrm{~g} \mathrm{~cm}^{-3}$ [20]. For example, incorporation of a wood-based biochar at $10 \mathrm{Mg} \mathrm{ha}^{-1}(\sim 0.5$ mass $\%$ soil) into the top $15 \mathrm{~cm}$ soil of a fallow land [74] or mixing a wheat straw-derived biochar at $10 \mathrm{Mg} \mathrm{ha}^{-1}$ (equivalent to 0.75 mass\%) with the top $10 \mathrm{~cm}$ soil of a maize field [75] had little influence on the soil bulk density measured 6 months after the biochar application. Even at a 2 mass $\%$ amendment rate, a rice husk-derived biochar did not significantly reduce the bulk density of paddy soil pots after $100 \mathrm{~d}$ of water flooding [76]. Blending a pecan shell-based biochar at $1 \mathrm{mass} \%$ with a loamy sand generated negligible impacts on the penetration resistance of packed soil columns following 70-d laboratory incubation [77]. No significant changes in the available water capacity were detected when sandy soils were amended with biochars at $10 \mathrm{Mg} \mathrm{ha}^{-1}[74,78,79]$. Most studies demonstrating noticeable improvements of biochar-amended 
soils in WHC and AWC used $\geq 1$ mass $\%$ amendment rates [35]. Hardie et al. reported that amending the top 10-cm sandy loam soil in an apple orchard with tree greenwaste-derived biochar at $47 \mathrm{Mg} \mathrm{ha}^{-1}$ (equivalent to 3 mass\% soil) improved little the soil aggregate stability (measured 30 months after biochar incorporation) [80]. At excessively low application rates, biochar generates little or marginal effect on soil chemical properties and plant growth. For instance, Panaque et al. did not observe any significant changes in soil pH, EC, WHC, and sunflower development when a calcareous soil was amended with pine wood-, paper sludge-, and sewage sludge-derived biochars at $1.5 \mathrm{Mg} \mathrm{ha}^{-1}$ [50]. Regardless of application rates, biochar amendment is transient in neutralizing soil acidity and supplementing plant nutrients. Incorporation of a wood-derived biochar $(\mathrm{pH} 9.2)$ in the top $0-5 \mathrm{~cm}$ Oxisol (pH 3.9) of maize plots at $8 \mathrm{Mg} \mathrm{ha}^{-1}\left(\sim 1.2\right.$ mass $\%$ ) and $20 \mathrm{Mg} \mathrm{ha}^{-1}$ ( 3.0 mass $\%$ ) increased the soil $\mathrm{pH}$ by 0.0 and 0.1 units, respectively, measured 4 years of the biochar application [51]. Amendment with ash-rich biochars (e.g., products derived from manures and many crop residues) at $<1$ mass $\%$ may markedly stimulate the growth of plants in low-fertility soils. The stimulation, however, is primarily a result of the additional mineral nutrients (e.g., $\mathrm{K}^{+}, \mathrm{Ca}^{2+}, \mathrm{Mg}^{2+}, \mathrm{PO}_{4}{ }^{3-}$, and $\mathrm{SO}_{4}{ }^{2-}$ ) introduced through biochar addition [67]. The effect typically becomes minimal after one or two growing seasons. On the other hand, over application (rates dependent on the biochar source and the soil type) of biochar may inhibit the growth of the first crop owning potentially to the resulting high soil salinity, alkalinity, and soil C:N ratio (limited $\mathrm{N}$ availability) [81-83]. Using potting experiments Rondon et al. found that soil amendment with wood-derived biochar at 9 mass $\%$ significantly restricted the biomass production and $\mathrm{N}$ uptake of the test common bean plants [84].

Many biochar products are strongly alkaline and saline, demonstrating a $\mathrm{pH}$ value greater than 10.0 (up to 11.5) and an EC level above $3.5 \mathrm{dS} \mathrm{m}^{-1}$ (up to $31 \mathrm{dS} \mathrm{m}^{-1}$ ) in 1:5 solid/water extracts. For example, poultry litter-derived biochar manufactured through $600{ }^{\circ} \mathrm{C}$ slow pyrolysis showed $\mathrm{pH} 11.5$ and EC $31 \mathrm{dS} \mathrm{m}^{-1}$ (in 1:5 solid/water extracts) [10]. When these types of biochar products are selected, the amendment rate should be controlled to ensure the treated soils have a $\mathrm{pH}$ value less than 7.5 and an EC value less than $2.7 \mathrm{dS} \mathrm{m}^{-1}$ (in 1:1 solid/water slurry; equivalent to $4 \mathrm{dS} \mathrm{m}^{-1}$ in saturated soil paste); otherwise the treated soils become alkaline and/or saline, restricting the growth of many crops and decreasing the plant availability of various soil nutrients including $\mathrm{P}, \mathrm{Fe}, \mathrm{Mn}, \mathrm{Cu}, \mathrm{Zn}$, and B [30]. Pre-tests may be conducted to determine the maximum allowable amendment rates of individual biochar products in single applications. When a sandy loam soil (pH 6.5 and EC $0.12 \mathrm{dS} \mathrm{m}^{-1}$ in 1:1 solid/water slurry) was amended with a poultry litter-derived biochar ( $\mathrm{pH} 10.3$ and EC $26.6 \mathrm{dS} \mathrm{m}^{-1}$ in $1: 5 \mathrm{solid} /$ water extracts) at 2 mass $\%$, the $\mathrm{pH}$ of the treated soil was elevated to 7.1 and the EC to $2.8 \mathrm{dS}$ $\mathrm{m}^{-1}$ (in 1:1 solid/water slurry) [44], a threshold condition for the optimal growth of plants sensitive to acidity and salinity. At a 3 mass $\%$ amendment rate, the poultry litter-derived biochar inhibited the seedling development of winter wheat growing in the treated soil [26]. To protect the in-season crops, it could be concluded that the soil amendment rate of poultry litter-derived biochar should not exceed 2 mass $\%$.

We conducted greenhouse potting experiments to investigate the source and application rate effects of biochar amendment on crop productivity. Biochars were separately produced from fallen deciduous tree leaves (TL), air-dry corn stover (CS), air-dry wheat straw (WS), and poultry litter (PL) pellets through $400{ }^{\circ} \mathrm{C}$ complete slow pyrolysis [10]. The biochars were ground to $<2 \mathrm{~mm}$ and referred to as TL, CS, WS, and PL biochars, respectively. The $\mathrm{pH}$ values of these biochars (in 1:5 w/w solid/water slurry) were 10.4, 10.5, 7.6, and 10.1, respectively; and the EC values (1:5 w/w solid/water extract) were $4.03,11.34,0.77$, and $23.59 \mathrm{dS} \mathrm{m}^{-1}$, respectively. A Greenwich sandy loam (coarse-loamy, mixed, semiactive, mesic Typic Hapludults) (pH 6.5 and EC $0.12 \mathrm{dS} \mathrm{m}^{-1}$ in 1:1 soil/water slurry) was collected from a local corn field and homogenized to $<4 \mathrm{~mm}$. In one trial, the soil was amended with PL biochar at $0,1,2$, and 3 mass $\%$, respectively, with thorough mixing. The amended soils were adjusted to $18 \%$ moisture content ( $75 \%$ of WHC) and packed into plastic pots $(18 \mathrm{~cm}$ height and $19 \mathrm{~cm}$ inner diameter). Additional soil pots receiving chemical fertilization at $100 \mathrm{~kg} \mathrm{~N}^{-1}$ (by incorporating $\mathrm{NH}_{4} \mathrm{NO}_{3}$ at $0.37 \mathrm{~g} \mathrm{~kg}^{-1}$ soil) and $25 \mathrm{~kg} \mathrm{P} \mathrm{ha}^{-1}$ (by adding $\mathrm{KH}_{2} \mathrm{PO}_{4}$ at $0.14 \mathrm{~g} \mathrm{~kg}^{-1}$ soil), raw PL amendment at 
$4.5 \mathrm{~g} \mathrm{~kg}^{-1}$ soil (equivalent to $3.3 \mathrm{Mg} \mathrm{ha}^{-1}$ ) to give $100 \mathrm{~kg} \mathrm{~N}$ ha- $^{-1}$, raw TL amendment at 2 mass\%, TL biochar amendment at 2 mass $\%$, and combined TL biochar amendment ( 2 mass $\%$ ) and chemical fertilization (100 kg N and $25 \mathrm{~kg} \mathrm{P} \mathrm{ha}^{-1}$ ) were also prepared following the same procedures. The soil pots representing 9 triplicated treatments were placed in a greenhouse. To each pot 10 winter wheat (Triticum aestivum) seeds were sown at $4 \mathrm{~cm}$ depth in the soil. The soil moisture content was maintained at $15 \%-20 \%$ by spraying tap water. The seed germination rate was $90 \%-100 \%$ in all the pots, not influenced by the treatments. After growing in the greenhouse for 84 days, the wheat plants were harvested by collecting the above-ground biomass and measured for the dry biomass yield of each pot. The average biomass yield data of the nine treatments were statistically compared using the Fisher's least significance difference (LSD) method. In another trial, similar soil pots were prepared with five distinct treatments: 1) chemical fertilization (Chem NP) — soil was fertilized by thorough incorporation of $\mathrm{NH}_{4} \mathrm{NO}_{3}$ at $150 \mathrm{~kg} \mathrm{~N}^{-1}$ and $\mathrm{KH}_{2} \mathrm{PO}_{4}$ at $25 \mathrm{~kg} \mathrm{P} \mathrm{ha}^{-1}$;2) Raw CS-NP—soil was amended with raw corn stover $(<1 \mathrm{~mm})$ at 5 mass $\%$ in addition to the chemical fertilization; 3) CS biochar-NP—soil was amended with CS biochar at 5 mass $\%$ in addition to the chemical fertilization; 4 ) Raw WS-NP—soil was amended with raw wheat straw $(<1 \mathrm{~mm})$ at 5 mass $\%$ in addition to the chemical fertilization; and 5 ) WS biochar-NP-soil was amended with WS biochar at 5 mass $\%$ in addition to the chemical fertilization. Five germinated seeds of spinach (Spinacia oleracea) were planted in each pot at a 3 -cm depth from the surface. After 45 days of greenhouse growing, the spinach plants were harvested by cutting at the soil surface. The fresh spinach biomass yield of each soil pot was measured and converted to values in $\mathrm{g} \mathrm{m}^{-2}$. The results indicated that amending a sandy loam soil with poultry litter-based biochar at 1-3 mass $\%$ significantly promoted the growth and biomass production of winter wheat (Figure 2). At a 3 mass $\%$ amendment rate, however, the plant seedling growth was visibly inhibited (likely due to the introduced salinity toxicity). Relative to the control soil without any amendments, TL biochar amendment (at 2 mass\%) alone slightly decreased the wheat biomass yield; when combined with chemical fertilization, the TL biochar amendment remarkably promoted the biomass yield (Figure 2). In comparison with the chemical fertilization alone, both Chem NP-combined 5 mass $\%$ CS biochar and 5 mass \% WS biochar amendments significantly increased the growth and biomass yield of spinach, whereas both Chem NP-combined 5 mass $\%$ raw CS and 5 mass $\%$ raw WS amendments generated clearly opposite effects (Figure 2). The results indicate that soil amendment with manure-derived biochars alone at 1-3 mass $\%$ evidently promotes plant growth. Soil amendment at 2-5 mass $\%$ with low-nutrient biochars like those derived from wood and crop residues requires combined chemical $\mathrm{N}$ and $\mathrm{P}$ fertilization to achieve the plant growth promoting effects. The synergic effects of biochar amendment in combination with chemical fertilization were validated by other researchers $[69,85]$.

In field trials, a wide range of biochar amendment rates from 5 to $50 \mathrm{Mg} \mathrm{ha}^{-1}$ has been employed, with higher rates yielding generally greater results in enhancing soil health $[67,86]$. Nevertheless, the market price of commercial biochar products has been unaffordably high (e.g., US\$100 per metric ton as the lowest price in 2018), restricting application of this desirable soil amendment at large scale and high rates [87]. Consequently, the low rate of $10 \mathrm{Mg} \mathrm{ha}^{-1}$ ( $\sim 0.5 \mathrm{mass} \%$ assuming thorough incorporation in the top $15 \mathrm{~cm}$ soil layer) has been the most common select in field biochar applications [67]. Depending on the biochar source and the soil type, biochar amendment at as low as 0.1 mass $\%\left(2 \mathrm{Mg} \mathrm{ha}^{-1}\right)$ may yield significant effects on plant growth [88]. Our research indicates that to secure the evident, long-term soil health improvement benefits, wood- and crop residue-derived biochars may be applied cumulatively at $2-5$ mass $\%$ soil $\left(40-100 \mathrm{Mg} \mathrm{ha}^{-1}\right)$ and manure-derived biochars be applied at 1-3 mass $\%$ soil (20-60 $\left.\mathrm{Mg} \mathrm{ha}^{-1}\right)$ to cropland. The practical biochar amendment rates should be further confirmed by soil $\mathrm{pH}$ and EC prescreening tests. 

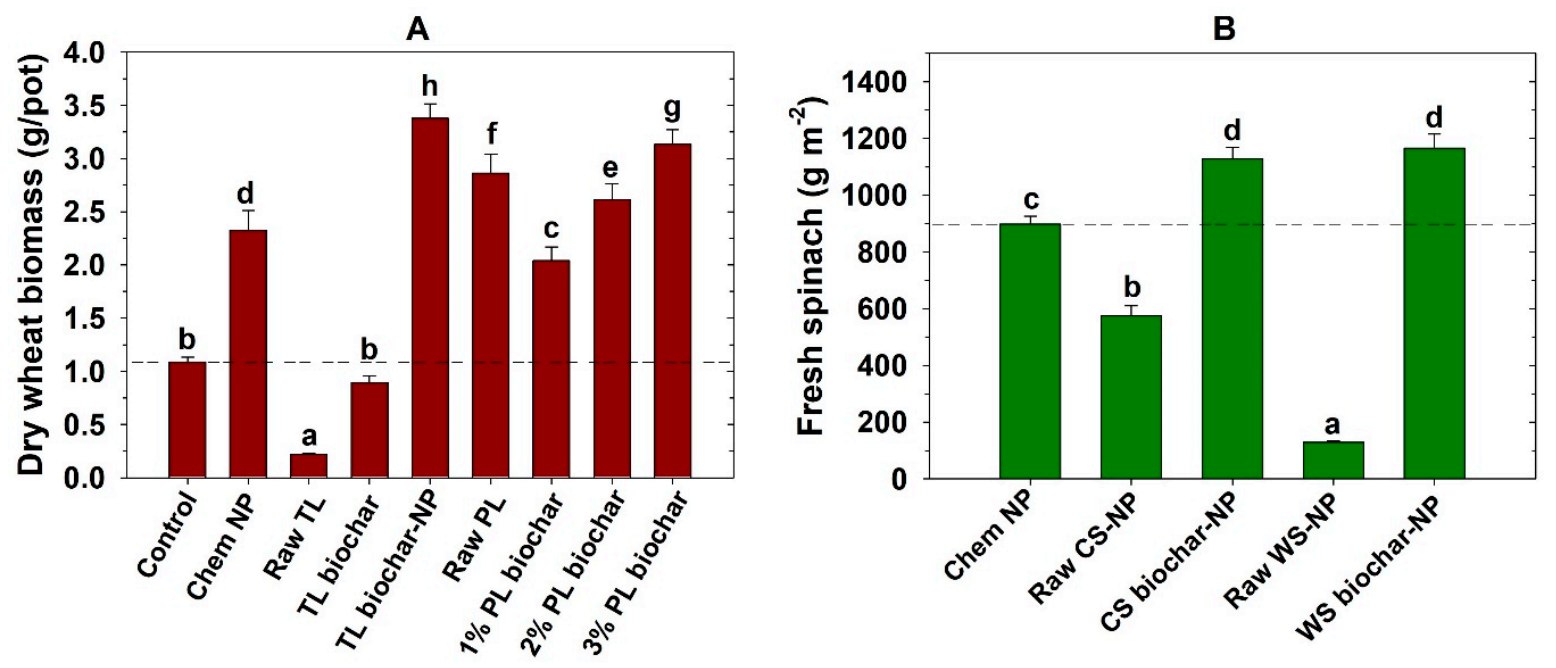

Figure 2. Biomass production of (A) winter wheat and (B) spinach in a sandy loam amended with biochars derived from different organic residues at varied amendment rates. Data are means of triplicate measurements. Error bars represent standard deviation of triplicate measurements. TL-tree leaf; PL_poultry litter; CS—corn stover; WS—wheat straw; NP—nitrogen and phosphorus fertilization.

\section{The Right Placement in Soil}

Soil texture, $\mathrm{pH}, \mathrm{EC}, \mathrm{OC}$ content, available nutrient level, and other properties influence the beneficial effects that could be attained through biochar amendment. Meta-analysis of the reported biochar studies illustrates that strongly acidic (e.g., $\mathrm{pH}<5.5$ ), coarse-textured soils generally respond more in improved overall health and crop productivity to biochar amendment than neutral or alkaline, fine-textured soils [35,67]. For instance, application of biochar at $>10 \mathrm{Mg} \mathrm{ha}^{-1}$ was able to enhance the $\mathrm{P}$ availability of $\mathrm{pH}<7.5$ agricultural soils but had little influence on that of alkaline $(\mathrm{pH}>7.5)$ soils [89]. Therefore, the type of soil should be examined upon biochar amendment. To maximize its benefits, biochar should be applied to acidic (i.e., $\mathrm{pH}<6.5$ ), strongly leached soils with low $\mathrm{OC}$ contents (e.g., $<10 \mathrm{~g} \mathrm{OC} \mathrm{kg}^{-1}$ soil or organic matter content $<2 \%$ ) [6]. To alkaline soils (e.g., $\mathrm{pH}>7.5$ ), biochar amendment may not be appropriate. If practiced, wood-derived biochars (relatively low in mineral ash content and lime equivalence) should be considered over other sources of biochars.

High-quality biochars are rather recalcitrant in the natural environment and can remain in soil over hundreds of years [4]. The short-term benefits (e.g., acid neutralization and nutrient supply) of biochar amendment may dissipate in one or several growing seasons, but the long-term benefits (e.g., improved water and nutrient retention and soil aggregation) will everlastingly persist. At sufficiently high rates, biochar amendment should be a "once-a-life" practice; applying biochar to each crop is clearly not necessary [86]. Consecutive biochar applications may be implemented to bring the cumulative amendment rates to the optimal levels if single applications were carried out at lower rates.

Thorough mixing with soil is the most efficient method for applying biochar to improve the overall soil health. This method has been extensively used in research and field trials. At occasions when soil incorporation is not feasible such as biochar amendment to perennial crops and grassland, surface application by broadcasting, banding, or sidedressing may be practiced. Surface-applied biochar functions mainly as a sterilized physical cover; the soil health improvement benefits are barely realized. Furthermore, biochar on the land surface reduces the land albedo and is subject to severe erosion losses by water and wind $[74,86]$. Subsurface application of biochar can be performed by tillage following broadcasting, band drilling, trenching, and localized holing [84]. Broadcasting followed by soil incorporation through multi-round conventional tillage is effective to mix the applied biochar with the top 15-20 cm soil, through which the overall soil health of the entire cropland can be enhanced. The vast majority of effective plant roots are in the top 30-cm soil layer, with many crops having the top $15 \mathrm{~cm}$ soil as the root zone $[90,91]$. In field trials, biochar incorporation into the $0-5 \mathrm{~cm}$ or $0-10$ 
$\mathrm{cm}$ soil layer was tested [50,74]. It is apparent that the health improvement effects would be limited to the treated soil layer. Migration of fine biochar particles in the soil profile may occur [50], yet the process is slow and happens only in preferential flow channels. To attain the long-term soil health improvement effects, biochar should be spread evenly over the land surface at the pre-determined rate and immediately incorporated in the crop-root-zone soil by tillage. Even so, relatively uniform distribution of biochar in soil is challenging to achieve, especially for products with a wide particle size distribution (e.g., from $<0.05 \mathrm{~mm}$ to $>10 \mathrm{~mm}$ ). Processing biochar into $<2 \mathrm{~mm}$ particles would greatly facilitate the soil mixing effect. Compared with coarser particles, biochar in $<2 \mathrm{~mm}$ particles is also more effective to enhance soil water retention [92].

Commercial biochar products contain significant portions of fine particles (e.g., $<0.5 \mathrm{~mm}$ ). Fine, dry biochar particles at a low envelope density (e.g., $\sim 0.52 \mathrm{~g} \mathrm{~cm}^{-3}$ ) are readily shifting in the presence of any tangible air current (wind), forming dust in the air and causing air pollution. Up to 25 mass $\%$ of biochar could be lost during field broadcasting application [83]. To reduce the dust formation and the related biochar losses, biochar may be moistened with water or mixed with manure, sludge, and compost prior to field application $[93,94]$. Dust formation becomes minimal when moistened biochar is applied under low-wind (i.e., $<8 \mathrm{~km} \mathrm{~h}^{-1}$ ) weather conditions.

\section{Conclusions}

Biochar is a promising soil amendment able to persistently improve soil health and promote crop production. Accordingly, best management programs need to be developed to maximize the benefits of biochar amendment. Amending soil with biochar should follow the 3R principles: right biochar source, right application rate, and right placement in soil. Biochar products vary significantly in composition and quality characteristics with the feedstock type and the production conditions. Biochars, in particular those manufactured from wood debris and crop residues do not contain significant contents of plant nutrients (e.g., $\mathrm{N}$ and $\mathrm{P}$ ) and, therefore, should not be expected to serve as a chemical fertilizer alternative and function as a major nutrient source to crops. The promoting effects of biochar amendment on crop production may not be achieved without combined chemical fertilization. The long-term effects on improving soil health should be highlighted with the most value in biochar application programs. The long-term capability of biochar to enhance soil health through persistently ameliorating soil physical, chemical, and biological properties is largely determined by its environmental recalcitrance and water- and nutrient-holding capacities. Desirable biochar products with sufficiently high recalcitrance (stability) and water- and nutrient-retention abilities are prepared through complete pyrolysis of biomass materials. Given complete pyrolysis for the same feed to experience thorough pyrolytic decomposition in the pyrolysis reactor, biochar products generated at a higher pyrolysis temperature in the range of $300-600{ }^{\circ} \mathrm{C}$ possess greater stability, alkalinity, and water-holding capacity. In field applications, biochar should be preferentially applied to acidic, highly leached soils. The treated soils should maintain a $\mathrm{pH}$ value less than 7.5 and an EC level below 2.7 $\mathrm{dS} \mathrm{m}^{-1}$ (in 1:1 soil/water slurry). The appropriate application rates (one time or cumulatively) are recommended at $2-5$ mass $\%$ soil ( $1 \%$ is equivalent to $\left.20 \mathrm{Mg} \mathrm{ha}^{-1}\right)$ for wood- and crop residue-derived biochars and at 1-3 mass \% soil for manure-derived biochars to achieve evident, long-term soil health improvement. Biochar should be processed to granular particle sizes and moistened to $100 \%$ water content (dry mass base) or mixed with compost upon field application. The applied biochar should be immediately incorporated into the root zone (e.g., top $15-20 \mathrm{~cm}$ ) soil with thorough mixing. Combination with chemical fertilization is necessary to attain the synergic beneficial effects of biochar amendment on crop growth.

Funding: Financial support for acquiring and compiling the research information in this paper was partially from the USDA-NRCS grant No. NR183A750010C001 and the USDA-NIFA Evans-Allen project No. 1017883.

Conflicts of Interest: The authors declare no conflict of interest. 


\section{References}

1. Sombroek, W.G. Amazon Soils: A Reconnaissance of the Soils of the Brazilian Amazon Region; Centre for Agricultural Publications and Documentation: Wageningen, The Netherlands, 1966.

2. Kern, D.C.; D’Aquino, G.; Rodrigues, T.E.; Frazao, F.J.L.; Sombroek, W.; Myers, T.P.; Neves, E.G. Distribution of Amazonian Dark Earths (terra preta) in the Brazilian Amazon. In Amazonian Dark Earths: Origin, Properties, Management; Lehmann, J., Kern, D., Glaser, B., Woods, W.I., Eds.; Kluwer Academic Publishers: Dordrecht, The Netherlands, 2003; pp. 105-124.

3. Glaser, B.; Balashov, E.; Haumaier, L.; Guggenberger, G.; Zech, W. Black carbon in density fractions of anthropogenic soils of the Brazilian Amazon region. Org. Geochem. 2000, 31, 669-678. [CrossRef]

4. Guo, M. Pyrogenic carbon in Terra Preta soils. In Agricultural and Environmental Applications of Biochar: Advances and Barriers; Guo, M., He, Z., Uchimiya, S.M., Eds.; SSSA Spec. Publ. 63; Soil Science Society of America: Madison, WI, USA, 2016; pp. 15-27.

5. USDA-NRCS. Soil Health; Natural Resources Conservation Service, U.S. Department of Agriculture: Washington, DC, USA, 2012. Available online: https://www.nrcs.usda.gov/wps/portal/nrcs/main/soils/health/ (accessed on 24 September 2019).

6. Guo, M.; He, Z.; Uchimiya, S.M. Introduction to biochar as an agricultural and environmental amendment. In Agricultural and Environmental Applications of Biochar: Advances and Barriers; Guo, M., He, Z., Uchimiya, S.M., Eds.; SSSA Spec. Publ. 63; Soil Science Society of America: Madison, WI, USA, 2016; pp. 1-14.

7. Lone, A.H.; Najar, G.R.; Ganie, M.A.; Sofi, J.A.; Ali, T. Biochar for sustainable soil health: A review of prospects and concerns. Pedosphere 2015, 25, 639-653. [CrossRef]

8. Novak, J.M.; Ippolito, J.A.; Lentz, R.D.; Spokas, K.A.; Bolster, C.H.; Sistani, K.; Trippe, K.M.; Phillips, C.L.; Johnson, M.G. Soil health, crop productivity, microbial transport, and mine spoil response to biochars. BioEnerg. Res. 2016, 9, 454-464. [CrossRef]

9. Bista, P.; Ghimire, R.; Machado, S.; Pritchett, L. Biochar effects on soil properties and wheat biomass vary with fertility management. Agronomy 2019, 9, 623. [CrossRef]

10. Song, W.; Guo, M. Quality variations of poultry litter biochars generated at different pyrolysis temperatures. J. Anal. Appl. Pyrolysis 2012, 94, 138-145. [CrossRef]

11. Kloss, S.; Zehetner, F.; Dellantonio, A.; Hamid, R.; Ottner, F.; Liedtke, V.; Schwanninger, M.; Gerzabek, M.H.; Soja, G. Characterization of slow pyrolysis biochars: Effects of feedstocks and pyrolysis temperature on biochar properties. J. Environ. Qual. 2012, 41, 990-1000. [CrossRef] [PubMed]

12. Windeatt, J.H.; Ross, A.B.; Williams, P.T.; Forster, P.M.; Nahil, M.A.; Singh, S. Characteristics of biochars from crop residues: Potential for carbon sequestration and soil amendment. J. Environ. Manag. 2014, 146, 189-197. [CrossRef] [PubMed]

13. Guo, M.; Xiao, P.; Li, H. Valorization of agricultural byproducts through conversion to biochar and bio-oil. In Byproducts from Agriculture and Fisheries: Adding Value for Food, Feed, Pharma and Fuels; Simpson, B.K., Kwofie, E.M., Aryee, A.N., Eds.; John Wiley \& Sons, Inc.: Somerset, NJ, USA, 2020; pp. 501-522.

14. Marchetti, R.; Castelli, F.; Orsi, A.; Sghedoni, L.; Bochicchio, D. Biochar from swine manure solids: Influence on carbon sequestration and Olsen phosphorus and mineral nitrogen dynamics in soil with and without digestate incorporation. Ital. J. Agron. 2012, 7, e26. [CrossRef]

15. Tian, J.; Miller, V.; Chiu, P.C.; Maresca, J.A.; Guo, M.; Imhoff, P.T. Nutrient release and ammonium sorption of poultry litter and wood biochars in stormwater treatment. Sci. Total Environ. 2016, 553, 596-606. [CrossRef]

16. Novak, J.M.; Lima, I.; Xing, B.; Gaskin, J.W.; Steiner, C.; Das, K.C.; Schomberg, H. Characterization of designer biochar produced at different temperatures and their effects on loamy sand. Ann. Environ. Sci. 2009, 3, 195-206.

17. Van Zwieten, L.; Kimber, S.; Morris, S.; Chan, K.Y.; Downie, A.; Rust, J.; Joseph, S.; Cowie, A. Effects of biochar from slow pyrolysis of papermill waste on agronomic performance and soil fertility. Plant Soil 2010, 327, 235-246. [CrossRef]

18. Roberts, D.A.; Paul, N.A.; Dworjanyn, S.A.; Bird, M.I.; de Nys, R. Biochar from commercially cultivated seaweed for soil amelioration. Sci. Rep. 2015, 5, 9665. [CrossRef] [PubMed]

19. Liu, Z.; Dugan, B.; Masiello, C.A.; Gonnermann, H.M. Biochar particle size, shape, and porosity act together to influence soil water properties. PLoS ONE 2017, 12, e0179079. [CrossRef] 
20. Guo, M. Application of biochar for soil physical improvement. In Agricultural and Environmental Applications of Biochar: Advances and Barriers; Guo, M., He, Z., Uchimiya, S.M., Eds.; SSSA Spec. Publ. 63; Soil Science Society of America: Madison, WI, USA, 2016; pp. 101-122.

21. Ouyang, L.; Wang, F.; Tang, J.; Yu, L.; Zhang, R. Effects of biochar amendment on soil aggregates and hydraulic properties. J. Soil Sci. Plant Nutr. 2013, 13, 991-1002. [CrossRef]

22. Kolb, S.E.; Fermanich, K.J.; Dornbush, M.E. Effect of charcoal quantity on microbial biomass and activity in temperate soils. Soil Sci. Soc. Am. J. 2009, 73, 1173-1181. [CrossRef]

23. Hseu, Z.; Jien, S.; Chien, W.; Liou, R.C. Impacts of biochar on physical properties and erosion potential of a mudstone slopeland soil. Sci. World J. 2014. [CrossRef]

24. Peake, L.R.; Reid, B.J.; Tang, X. Quantifying the influence of biochar on the physical and hydrological properties of dissimilar soils. Geoderma 2014, 235-236, 182-190. [CrossRef]

25. Li, Y.; Zhang, F.; Yang, M.; Zhang, J.; Xie, Y. Impacts of biochar application rates and particle sizes on runoff and soil loss in small cultivated loess plots under simulated rainfall. Sci. Total Environ. 2019, 649, 1403-1413. [CrossRef]

26. Laghari, M.; Mirjat, M.S.; Hu, Z.; Fazal, S.; Xiao, B.; Hu, M.; Chen, Z.; Guo, D. Effects of biochar application rate on sandy desert soil properties and sorghum growth. CATENA 2015, 135, 313-320. [CrossRef]

27. Revell, K.T.; Maguire, R.O.; Agblevor, F.A. Influence of poultry litter biochar on soil properties and plant growth. Soil Sci. 2012, 177, 402-408. [CrossRef]

28. Johnston, A.M.; Bruulsema, T.W. 4R nutrient stewardship for improved nutrient use efficiency. Procedia Eng. 2014, 83, 365-370. [CrossRef]

29. Liu, G.; Morgan, K.; Li, Y.; Zotarelli, L.; Wang, Q.; Devalerio, J. What is $4 R$ Nutrient Stewardship? University of Florida IFAS Extension: Gainesville, FL, USA, 2015; Available online: https://edis.ifas.ufl.edu/hs1264 (accessed on 12 October 2019).

30. Weil, R.R.; Brady, N.C. The Nature and Properties of Soils; Prentice Hall: Upper Saddle River, NJ, USA, 2017.

31. Soil Health Institute. Tier 1 Indicators of Soil Health; Soil Health Institute: Morrisville, NC, USA, 2017; Available online: https://soilhealthinstitute.org/tier-1-indicators-soil-health/ (accessed on 14 October 2019).

32. Silveira, M.L.; Kohmann, M.M. Maintaining soil fertility and health for sustainable pastures. In Management Strategies for Sustainable Cattle Production in Southern Pastures; Rouquette, J.M., Aiken, G., Eds.; Academic Press: San Diego, CA, USA, 2020; pp. 35-58.

33. Moebius-Clune, B.N.; Moebiue-Clune, D.J.; Gugino, B.K.; Idowu, O.J.; Schindelbeck, R.R.; Ristow, A.J.; van Es, H.M.; Thies, J.E.; Shayler, H.A.; McBride, M.B.; et al. Comprehensive Assessment of Soil Health, 3rd ed.; Cornell University: Ithaca, NY, USA, 2017; pp. 19-101.

34. Rahman, G.K.M.M.; Rahman, M.M.; Alam, M.S.; Kamal, M.Z.; Mashuk, H.A.; Datta, R.; Meena, R.S. Biochar and organic amendments for sustainable soil carbon and soil health. In Carbon and Nitrogen Cycling in Soil; Datta, R., Meena, R., Pathan, S., Ceccherini, M., Eds.; Springer: Singapore, 2020; pp. 45-85.

35. Blanco-Canqui, H. Biochar and soil physical properties. Soil Sci. Soc. Am. J. 2017, 81, 687-711. [CrossRef]

36. Igalavithana, A.D.; Ok, Y.S.; Usman, A.R.A.; Al-Wabel, M.I.; Oleszczuk, P.; Lee, S.S. The effects of biochar amendment on soil fertility. In Agricultural and Environmental Applications of Biochar: Advances and Barriers; Guo, M., He, Z., Uchimiya, S.M., Eds.; SSSA Spec. Publ. 63; Soil Science Society of America: Madison, WI, USA, 2016; pp. 123-144.

37. Paz-Ferreiro, J.; Mendez, A.; Gasco, G. Application of biochar for soil biological improvement. In Agricultural and Environmental Applications of Biochar: Advances and Barriers; Guo, M., He, Z., Uchimiya, S.M., Eds.; SSSA Spec. Publ. 63; Soil Science Society of America: Madison, WI, USA, 2016; pp. 145-174.

38. Karaosmanoglu, F.; Ergudenler, A.; Sever, A. Biochar from the straw-stalk of rapeseed plant. Energy Fuels 2000, 14, 336-339. [CrossRef]

39. Mullen, C.A.; Boateng, A.A.; Goldberg, N.M.; Lima, I.M.; Laird, D.A.; Hicks, K.B. Bio-oil and bio-char production from corn cobs and stover by fast pyrolysis. Biomass Bioenergy 2010, 34, 67-74. [CrossRef]

40. Singh, B.; Singh, B.P.; Cowie, A.L. Characterization and evaluation of biochars for their application as a soil amendment. Soil Res. 2010, 48, 516-525. [CrossRef]

41. Arazo, R.O.; Genuino, D.A.D.; de Luna, M.D.G.; Capareda, S.C. Bio-oil production from dry sewage sludge by fast pyrolysis in an electrically-heated fluidized bed reactor. Sustain. Environ. Res. 2017, 27, 7-14. [CrossRef] 
42. Adhikari, S.; Gascó, G.; Méndez, A.; Surapaneni, A.; Jegatheesan, V.; Shah, K.; Paz-Ferreiro, J. Influence of pyrolysis parameters on phosphorus fractions of biosolids derived biochar. Sci. Total Environ. 2019, 695, 133846. [CrossRef]

43. Briggs, C.; Breiner, J.M.; Graham, R.C. Physical and chemical properties of pinus ponderosa charcoal: Implications for soil modification. Soil Sci. 2012, 177, 263-268. [CrossRef]

44. Wang, Y.; Lin, Y.; Chiu, P.; Imhoff, P.; Guo, M. Phosphorus release behaviors of poultry litter biochar as a soil amendment. Sci. Total Environ. 2015, 512-513, 454-463. [CrossRef]

45. Lehmann, J.; da Silva, J.P.; Steiner, C.; Nehls, T.; Zech, W.; Glaser, B. Nutrient availability and leaching in an archaeological Anthrosol and a Ferralsol of the Central Amazon basin: Fertilizer, manure and charcoal amendments. Plant Soil 2003, 249, 343-357. [CrossRef]

46. Knowles, O.A.; Robinson, B.H.; Contangelo, A.; Clucas, L. Biochar for the mitigation of nitrate leaching from soil amended with biosolids. Sci. Total. Environ. 2011, 409, 3206-3210. [CrossRef] [PubMed]

47. Meerts, P. Mineral nutrient concentrations in sapwood and heartwood: A literature review. Ann. For. Sci. 2002, 59, 713-722. [CrossRef]

48. Guo, M.; Shen, Y. Transformation and persistence of biochar carbon in soil. In Proceedings of the ASA-CSSA-SSSA International Annul Meeting, San Antonio, TX, USA, 18 October 2011.

49. Gai, X.; Wang, H.; Zhai, L.; Liu, S.; Ren, T.; Liu, H. Effects of feedstock and pyrolysis temperature on biochar adsorption of ammonium and nitrate. PLoS ONE 2014, 9, e113888. [CrossRef] [PubMed]

50. Hardie, M.; Clothier, B.; Bound, S.; Oliver, G.; Close, D. Does biochar influence soil physical properties and soil water availability? Plant Soil 2014, 376, 347-361. [CrossRef]

51. Paneque, M.; Rosa, J.M.; Franco-Navarro, J.D.; Colmenero-Flores, J.M.; Knicker, H. Effect of biochar amendment on morphology, productivity and water relations of sunflower plants under non-irrigation conditions. Catena 2016, 147, 280-287. [CrossRef]

52. Barskov, S.; Zappi, M.; Buchireddy, P.; Dufreche, S.; Guillory, J.; Gang, D.; Hernandez, R.; Bajpai, R.; Bauider, J.; Cooper, R.; et al. Torrefaction of biomass: A review of production methods for biocoal from cultured and waste lignocellulosic feedstocks. Renew. Energy 2019, 142, 624-642. [CrossRef]

53. Tekin, K.; Karagoa, S.; Bektas, S. A review of hydrothermal biomass processing. Renew. Sustain. Energy Rev. 2014, 40, 673-687. [CrossRef]

54. Naisse, C.; Alexis, M.; Plante, A.; Wiedner, K.; Glaser, B.; Pozzi, A.; Carcaillet, C.; Criscuoli, I.; Rumpel, C. Can biochar and hydrochar stability be assessed with chemical methods? Org. Geochem. 2013, 60, 40-44. [CrossRef]

55. Basu, P. Biomass Gasification and Pyrolysis: Practical Design and Theory; Academic Press: Burlington, MA, USA, 2010.

56. Zhang, J.; Liu, J.; Li, R. Effects of pyrolysis temperature and heating time on biochar obtained from the pyrolysis of straw and lignosulfonate. Bioresour. Technol. 2015, 176, 288-291. [CrossRef]

57. Intani, K.; Latif, S.; Islam, M.S.; Müller, J. Phytotoxicity of corncob biochar before and after heat treatment and washing. Sustainability 2019, 11, 30. [CrossRef]

58. Klasson, K.T.; Biohem, L.L.; Uchimiya, M.; Lima, M. Influence of biochar pyrolysis temperature and post-treatment on the uptake of mercury from flue gas. Fuel Process. Technol. 2014, 123, 27-33. [CrossRef]

59. Guo, M.; Song, W. Converting poultry litter to activated carbon: Optimal carbonization conditions and product sorption for benzene. Environ. Technol. 2011, 32, 1789-1798. [CrossRef] [PubMed]

60. Vamvuka, D. Bio-oil, solid and gaseous biofuels from biomass pyrolysis processes-An overview. Int. J. Energy Res. 2011, 35, 835-862. [CrossRef]

61. Demirbas, A. Effects of temperature and particle size on bio-char yield from pyrolysis of agricultural residues. J. Anal. Appl. Pyrolysis 2004, 72, 243-248. [CrossRef]

62. Guo, M.; Li, H.; Baldwin, B.; Morrison, J. Thermal processing of animal manure for bioenergy and biochar. In Animal Manure: Production, Characteristics, Environmental Concerns and Management; Waldrip, H.M., Pagliari, P.H., He, Z., Eds.; ASA Spec. Publ. 67; American Society of Agronomy: Madison, WI, USA, 2020. [CrossRef]

63. IBI. Standardized Product Definition and Product Testing Guidelines for Biochar that Is Used in Soil-Version 2.1; International Biochar Initiative: Westerville, OH, USA, 2015; Available online: http://www.biocharinternational.org/characterizationstandard (accessed on 13 October 2019). 
64. Camps-Arbestain, M.; Amonette, J.E.; Singh, B.; Wang, T.; Schmidt, H.P. A biochar classification system and associated test methods. In Biochar for Environmental Management: Science, Technology and Implementation; Lehmann, J., Joseph, S., Eds.; Routledge: Abingdon, UK, 2015; pp. 165-194.

65. Purdue University. Fundamentals of Soil Cation Exchange Capacity (CEC); Purdue University Cooperative Extension Service: West Lafayette, IN, USA, 1993; Available online: https:/www.extension.purdue.edu/ extmedia/AY/AY-238.html (accessed on 20 November 2019).

66. Pennell, K.D. Specific surface area. In Methods of Soil Analysis Part 4_Physical Methods; Dane, J.H., Topp, G.C., Eds.; Soil Science Society of America: Madison, WI, USA, 2002; pp. 295-315.

67. Steiner, C. Considerations in biochar characterization. In Agricultural and Environmental Applications of Biochar: Advances and Barriers; Guo, M., He, Z., Uchimiya, S.M., Eds.; SSSA Spec. Publ. 63; Soil Science Society of America: Madison, WI, USA, 2016; pp. 87-100.

68. Liu, X.; Zhang, A.; Ji, C.; Joseph, S.; Bian, R.; Li, L.; Pan, G.; Paz-Ferreiro, J. Biochar's effect on crop productivity and the dependence on experimental conditions_A meta-analysis of literature data. Plant Soil 2013, 373, 583-594. [CrossRef]

69. Ye, L.; Camps-Arbestain, M.; Shen, Q.; Lehmann, J.; Singh, B.; Sabir, M. Biochar effects on crop yields with and without fertilizer: A meta-analysis of field studies using separate controls. Soil Use Manag. 2019. [CrossRef]

70. Guo, M.; Song, W.; Kazda, R. Fertilizer value of lime-stabilized biosolids as a soil amendment. Agron. J. 2012, 104, 1679-1686. [CrossRef]

71. Li, W.; Feng, X.; Song, W.; Guo, M. Transformation of phosphorus in speciation and bioavailability during converting poultry litter to biochar. Front. Sustain. Food Syst. 2018, 2, 20. [CrossRef]

72. Lehmann, J.; Abiven, S.; Kleber, M.; Pan, G.; Singh, B.P.; Sohi, S.P.; Zimmerman, A.R. Persistence of biochar in soil. In Biochar for Environmental Management: Science, Technology and Implementation; Lehmann, J., Joseph, S., Eds.; Routledge: Abingdon, UK, 2015; pp. 235-282.

73. Steiner, C.; Das, K.C.; Garcia, M.; Forster, B.; Zech, W. Charcoal and smoke extract stimulate the soil microbial community in a highly weathered xanthic Ferralsol. Pedobiologia 2008, 51, 359-366. [CrossRef]

74. Xiao, Q.; Zhu, L.; Zhang, H.; Li, X.; Shen, Y.; Li, S. Soil amendment with biochar increases maize yields in a semi-arid region by improving soil quality and root growth. Crop Pasture Sci. 2016, 67, 495-507. [CrossRef]

75. Usowicz, B.; Lipiec, J.; Lukowski, M.; Marczewski, W.; Usowicz, J. The effect of biochar application on thermal properties and albedo of loess soil under grassland and fallow. Soil Tillage Res. 2016, 164, 45-51. [CrossRef]

76. Pratiwi, E.P.; Shinogi, Y. Rice husk biochar application to paddy soil and its effects on soil physical properties, plant growth, and methane emission. Paddy Water Environ. 2016, 14, 521-532. [CrossRef]

77. Busscher, W.J.; Novak, J.M.; Evans, D.E.; Watts, D.W.; Niandou, M.A.S.; Ahmedna, M. Influence of pecan biochar on physical properties of a Norfolk loamy sand. Soil Sci. 2010, 175, 10-14. [CrossRef]

78. Glab, T.; Palmowska, J.; Zaleski, T.; Gondek, K. Effect of biochar application on soil hydrological properties and physical quality of sandy soil. Geoderma 2016, 281, 11-20. [CrossRef]

79. Kameyama, K.; Miyamoto, T.; Iwata, Y.; Shiono, T. Effects of biochar produced from sugarcane bagasse at different pyrolysis temperatures on water retention of a calcaric dark red soil. Soil Sci. 2016, 181, 20-28. [CrossRef]

80. Major, J.; Rondon, M.; Molina, D.; Riha, S.J.; Lehman, J. Maize yield and nutrition during 4 years after biochar application to a Columbian savanna oxisol. Plant Soil 2010, 333, 117-128. [CrossRef]

81. Mavi, M.S.; Singh, G.; Singh, B.P.; Sekhon, B.S.; Choudhary, O.P.; Sagi, S.; Berry, R. Interactive effects of rice-residue biochar and $\mathrm{N}$-fertilizer on soil functions and crop biomass in contrasting soils. J. Soil Sci. Plant Nutr. 2018, 18, 41-59.

82. Haefele, S.M.; Konboon, Y.; Wongboon, W.; Amarante, S.; Maarifat, A.A.; Pfeiffer, E.M.; Knoblauch, C. Effects and fate of biochar from rice residues in rice-based systems. Field Crops Res. 2011, 121, 430-440. [CrossRef]

83. Gao, S.; DeLuca, T.H.; Cleveland, C.C. Biochar additions alter phosphorus and nitrogen availability in agricultural ecosystems: A meta-analysis. Sci. Total Environ. 2018, 654, 463-472. [CrossRef]

84. Rondon, M.A.; Lehmann, J.; Ramirez, J.; Hurtado, M. Biological nitrogen fixation by common beans (Phaseolus vulgaris L.) increases with bio-char additions. Biol. Fertil. Soils 2007, 43, 699-708. [CrossRef]

85. Zheng, Y.; Han, X.; Li, Y.; Yang, J.; Li, N.; An, N. Effects of biochar and straw application on the physicochemical and biological properties of paddy soils in northeast China. Sci. Rep. 2019, 9, 16531. [CrossRef] [PubMed] 
86. Major, J. Guidelines on Practical Aspects of Biochar Application to Field Soil in Various Soil Management Systems; International Biochar Initiative: Westerville, OH, USA, 2010; Available online: https://www.biocharinternational.org/wp-content/uploads/2018/04/IBI_Biochar_Application.pdf (accessed on 23 November 2019).

87. Robb, S.; Joseph, S. A Report on the Value of Biochar and Wood Vinegar: Practical Experience of Users in Australia and New Zealand; Australia New Zealand Biochar Initiative, Inc.: Tyagarah, Australia, 2019; Available online: https://www.anzbi.org/wp-content/uploads/2019/06/ANZBI-2019__-A-Report-on-theValue-of-Biochar-and-Wood-Vinegar-v-1.1.pdf (accessed on 24 November 2019).

88. Yang, Y.; Ma, S.; Zhao, Y.; Jing, M.; Xu, Y.; Chen, J. A field experiment on enhancement of crop yield by rice straw and corn stalk-derived biochar in Northern China. Sustainability 2015, 7, 13713-13725. [CrossRef]

89. Glaser, B.; Lehr, V. Biochar effects on phosphorus availability in agricultural soils: A meta-analysis. Sci. Rep. 2019, 9, 9338. [CrossRef] [PubMed]

90. Clemson University. The Hidden Half of the Plant; Clemson University: Clemson, SC, USA, 2017; Available online: https://www.clemson.edu/cafls/research/coastal/documents/hiddenhalfofplant.pdf (accessed on 23 November 2019).

91. USDA-NRCS. National Engineering Handbook: Part 652-Irrigation Guide; 210-vi-NEH; Natural Resources Conservation Service, United State Department of Agriculture: Washington, DC, USA, 1997; pp. 3-8.

92. Verheijen, F.G.A.; Zhuravel, A.; Silva, F.C.; Amaro, A.; Ben-Hur, M.; Keizer, J.J. The influence of biochar particle size and concentration on bulk density and maximum water holding capacity of sandy vs sandy loam soil in a column experiment. Geoderma 2019, 347, 194-202. [CrossRef]

93. Blackwell, P.; Riethmuller, G.; Collins, M. Biochar application to soil. In Biochar for Environmental Management: Science and Technology; Lehmann, J., Joseph, S., Eds.; Earthscan: London, UK, 2009; pp. 207-222.

94. Verheijen, F.; Jeffery, S.; Bastos, A.C.; van der Velde, M.; Diafas, I. Biochar Application to Soils: A Critical Scientific Review of Effects on Soil Properties, Processes and Functions; EUR 24099 EN; European Commission Joint Research Center: Ispra, Italy, 2010; pp. 49-50.

(C) 2020 by the author. Licensee MDPI, Basel, Switzerland. This article is an open access article distributed under the terms and conditions of the Creative Commons Attribution (CC BY) license (http://creativecommons.org/licenses/by/4.0/). 